\title{
Microbiological quality and physicochemical characterization of Brazilian bee pollen
}

\section{Vanilda Aparecida Soares de Arruda, Alexandre Vieria dos Santos, Davi} Figueiredo Sampaio, Elias da Silva Araújo, André Luís de Castro Peixoto, Maria Leticia Fernandes Estevinho \& Ligia Bicudo de Almeida-Muradian

To cite this article: Vanilda Aparecida Soares de Arruda, Alexandre Vieria dos Santos, Davi Figueiredo Sampaio, Elias da Silva Araújo, André Luís de Castro Peixoto, Maria Leticia Fernandes Estevinho \& Ligia Bicudo de Almeida-Muradian (2017) Microbiological quality and physicochemical characterization of Brazilian bee pollen, Journal of Apicultural Research, 56:3, 231-238, DOI: 10.1080/00218839.2017.1307715

To link to this article: https://doi.org/10.1080/00218839.2017.1307715

\section{曲 Published online: 30 Mar 2017.}

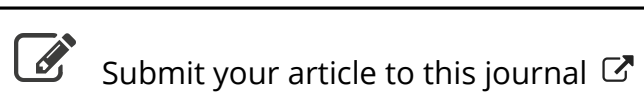

Џll Article views: 84

Q View related articles ¿

View Crossmark data ¿ 


\title{
ORIGINAL RESEARCH ARTICLE
}

\section{Microbiological quality and physicochemical characterization of Brazilian bee pollen}

\author{
Vanilda Aparecida Soares de Arruda ${ }^{a^{*}}$ (D), Alexandre Vieria dos Santos ${ }^{\mathrm{a}}$, Davi Figueiredo Sampaio ${ }^{\mathrm{a}}$, \\ Elias da Silva Araújo ${ }^{\mathrm{a}}$, André Luís de Castro Peixotob ${ }^{\mathrm{D}}$, Maria Leticia Fernandes Estevinho ${ }^{c}$ and \\ Ligia Bicudo de Almeida-Muradian ${ }^{\mathrm{a}}$ (D)
}

${ }^{a}$ Laboratory of Food Analysis, Department of Food and Experimental Nutrition, Pharmaceutical Science School, University of Sao Paulo, São Paulo, Brazil; ' Grupo de Química Tecnológica, Instituto Federal de São Paulo (IFSP), Capivari, Brazil; 'Agricultural College of Bragança, Polytechnic Institute of Bragança, Bragança, Portugal

(Received 20 July 2016; accepted 27 January 2017)

\begin{abstract}
Sixty-two commercial samples of dehydrated bee pollen (Apis mellifera bees) collected in Brazil (eight states and the Federal District) were analyzed for commercial quality (moisture, ash, lipids, proteins, and carbohydrates), and hygiene (aerobic mesophiles, yeasts and molds, coliforms, Escherichia coli, Staphylococcus aureus and sulfite-reducing Clostridium). The analyzed samples were within the regulatory limits established by the legislation for ash, lipid and protein, except for moisture content. The analyzed hygiene parameters evaluated for bee pollen are not regulated by the Brazilian legislation, and the data discussed can contribute to regulatory agencies. Only moderate and weak correlations were observed between dehydrated pollen samples and the parameters evaluated.
\end{abstract}

\section{Calidad microbiológica y caracterización fisicoquímica del polen de abeja}

\begin{abstract}
Se analizó la calidad comercial (humedad, cenizas, lípidos, proteínas e hidratos de carbono) e higiene (mesófilos aeróbicos, levaduras y mohos, coliformes, Escherichia coli, Staphylococcus aureus y Clostridium reductor de sulfito) de 62 muestras comerciales de polen de abejas deshidratadas (Apis mellifera abejas) recogidas en Brasil (ocho estados y el Distrito Federal). Las muestras analizadas se encontraban dentro de los límites reglamentarios establecidos por la legislación para las cenizas, lípidos y proteínas, con excepción del contenido de humedad. Los parámetros de higiene analizados para el polen de abejas no están regulados por la legislación brasileña y los datos discutidos pueden ser distribuidos a los organismos reguladores. Sólo se observaron correlaciones moderadas y débiles entre muestras de polen deshidratadas y los parámetros evaluados.
\end{abstract}

Keywords: bee pollen; food analysis; microbiological safety; nutrient; apicultural; Apis mellifera

\section{Introduction}

Bee pollen is used mainly as a natural food supplement with low levels of lipids, and may be of particular interest to those seeking a balanced diet. Besides Brazil, some countries such as Switzerland, Argentina and France have legally recognized bee pollen as a food supplement presenting identity and quality standards, as well as the limits for each parameter to be analyzed. Although this product is sold in many health food stores, bee pollen is not considered a food supplement by the Food and Drug Administration (FDA) in the USA and has not been marketed with special standards (Almeida-Muradian, Pamplona, Coimbra, \& Barth, 2005; Almeida-Muradian, Arruda, \& Barreto, 2012; Mundargi et al., 2016).

It would be useful to add specific standards to the legislation, for example, regarding the possible organic and inorganic contaminants or macroscopic and microscopic criteria. In addition, probably by the lack of scientific support, Brazilian Legislation does not require an expiry date for dehydrated bee pollen. Barreto, Funari, and Orsi (2005) examined the packaging of dehydrated bee pollen from seven different Brazilian States, observing that $59 \%$ of the samples were marketed in glass containers and $41 \%$ in plastic containers (jars or bags). Expiry dates from six months to three years were found on the labels for this product. Due to the nutritional and functional importance of the components present in food, it is necessary to control and to supervise the different elaboration processes, so as to ensure that the processed food supply could guarantee that the consumer gets all the nutrients in their most bioavailable form, and should be in accordance with the legislation requirements retaining their organoleptic properties (Torres, Guinand, \& Guerra, 2003; Hani et al., 2012).

The main physicochemical and nutritional composition of bee pollen in natura combined with the presence of micro-organisms naturally available in this product are conditions that have to be monitored for the good practices of bee pollen collection, transport, packaging and processing (Arruda, Freitas, Barth, Estevinho, \& Almeida-Muradian, 2013; Arruda, Pereira, Estevinho, \&

"Corresponding author. Email: cravoecanela.sp@usp.br 
Almeida-Muradian, 20I3; Arruda, Pereira, Freitas, Barth, \& Almeida-Muradian, 2013; Campos et al., 2008; DeMelo et al., 2016; Fatrcová-Šramková et al., 2013; Gabriele et al., 2015; Melo, Freitas, Barth, \& Almeida-Muradian, 2009; Melo \& Almeida-Muradian, 201I; Puig-Peña, Del-Risco-Ríos, Álvarez-Rivera, Leiva-Castillo, \& GarcíaNeninger, 20I2; Yang et al., 20I3; Sattler et al., 20I5). Also, there are a variety of microorganisms that could develop in this product (De-Melo, Estevinho, \& Almeida-Muradian, 20I5; Estevinho, Rodrigues, Pereira, \& Feás, 2012; Feás, Vázquez-Tato, Estevinho, Seijas, \& Iglesias, 2012; Morgano, Milani, Martins, \& RodriguezAmaya, 201I; Nogueira, Iglesias, Feás, \& Estevinho, 2012).

When assessing the quality of a food, it is essential to determine the safety from the microbiological point of view (Nardoni, D’Ascenzi, Rocchigiani, Moretti, \& Mancianti, 2016). In this paper, a study of the physicochemical composition and microbiological quality of commercial samples of dehydrated bee pollen produced in eight Brazilian States and in the Federal District. Within the context of the effects of rules and regulations on the food security of the product, the data presented are of particular importance because microbiological quality parameters are not regulated, nor is the standardization of methods for physicochemical and microbiological analysis.

\section{Materials and methods}

\section{Reagents and bee pollen samples}

The reagents used during the extraction procedures and other analytical methods were of analytical grade and were applied without further purification. Ultrapure water was prepared by Milli-Q Direct purification system (Millipore, Bedford, MA, USA). Sixty-two commercial samples of dehydrated bee pollen (Apis mellifera bees) were collected in the years 2009-2012 from the Federal District and eight Brazilian States (Bahia, Espirito Santo, Sergipe, Sao Paulo, Santa Catarina, Mato Grosso, Rio Grande do Norte and Rio Grande do Sul). The commercial samples received were kept in glass jars and stored in a freezer $\left(-18{ }^{\circ} \mathrm{C}\right)$ until analysis. Prior to analysis, the samples were homogenized and ground in analytical mill.

\section{Physicochemical determinations}

The gravimetric method was used to quantify moisture in the samples. Electronic precision scale Micronal BI60 balance, adjusted with infrared dryer Metler Toledo (LPI6), was used for the gravimetric determination. Approximately one gram was subjected to $85{ }^{\circ} \mathrm{C}$ in the infrared scale (Almeida-Muradian et al., 2012; Arruda, Pereira, Freitas, et al., 2013; Melo \& Almeida-Muradian, $20 \mathrm{II}$ ). Proteins were quantified by the Micro-Kjeldahl method, using factor 6.25 for converting the total nitro- gen into proteins (Almeida-Muradian \& Penteado, 2007; Almeida-Muradian et al., 2012; Arruda, Pereira, Freitas, et al., 20I3). Lipids were quantified using an intermittent Soxhlet extractor with diethyl ether as solvent (Almeida-Muradian \& Penteado, 2007; Almeida-Muradian et al., 2012; Arruda, Pereira, Freitas, et al., 2013). Ash was determined gravimetrically after incineration of the material in an oven at $550{ }^{\circ} \mathrm{C}$, up to constant weight (Almeida-Muradian et al., 2005, 2012; Arruda, Pereira, Freitas, et al., 20l3).

Quantification of fructose and glucose were performed by the Normal-Phase Liquid Chromatography method. Approximately 2.5 grams of dried bee pollen were mixed with $30 \mathrm{~mL}$ of water at $40{ }^{\circ} \mathrm{C}$, and the solution was heated for $15 \mathrm{~min}$ in a water bath at $60{ }^{\circ} \mathrm{C}$. The mixture was continuously swirled while $2 \mathrm{~mL}$ of each Carrez solution were added. The solution was then cooled at room temperature, and transferred to a $50 \mathrm{~mL}$ volumetric glassware; additional deionized water was used to complete the volumetric glassware. Finally, filtration by a $0.45 \mu \mathrm{m}$ membrane was used before HPLC injection (Burgner \& Feinberg, 1992; Martins, Morgano, Vicente, Baggio, \& Rodriguez-Amaya, 20II). The HPLC mobile phase consisted of acetonitrile and water $(85: 5 \mathrm{v} / \mathrm{v})$ a $1 \mathrm{ml} / \mathrm{min}$ flowrate. The HPLC system was equipped with two Shimadzu (LC-20AT) pumps, Shimadzu (SIL-20A Autosampler) autosampler; Shimadzu (IR-IOAXL) Refractive Index detector, and a normal phase column (Luna $\mathrm{NH}_{2} .250 \times 4.6 \mathrm{~mm}, 5 \mu \mathrm{m}$, Phenomenex Inc., Torrance, USA) with pre-column $\left(\right.$ Luna $\mathrm{NH}_{2}$. $10 \times 4.6 \mathrm{~mm}, 5 \mu \mathrm{m}$ ), thermostated at $40{ }^{\circ} \mathrm{C}$; Software LC-Solution, Shimadzu CBM-20A (SCL-IOAVP) system controller. The accuracy of the method to analyze glucose and fructose was determined by the method of addition and recovery of the analyte. Three concentration levels for the addition of analyte were explored $(50 ; 75$; and $100 \%$ of the expected concentration for bee pollen).

\section{Microbiological determinations}

Microbiological determinations were evaluated as previously described by Gomes, Dias, Moreira, Rodrigues, and Estevinho (20l0), Estevinho et al. (20I2), Feás et al., 20I2, and Nogueira et al. (20I2). All the microbial tests were performed in triplicate. Ten grams of each bee pollen sample were homogenized into $90 \mathrm{~mL}$ of peptone water solvent as sample preparation for the microbiological tests. Decimal dilutions were performed using the same solvent.

Aerobic mesophilic bacteria were counted onto standard plate count agar (PCA; Himedia, Mumbai, India) and incubated at $30^{\circ} \mathrm{C}$ for $48 \mathrm{~h}$ (NP-3788. 2002). Microbial counts were expressed as colony-forming units per gram of bee pollen $\left(\mathrm{CFU} \mathrm{g}^{-1}\right)$. Molds and yeasts enumerations were made onto DGI 8 agar Himedia and incubated at $25^{\circ} \mathrm{C}$ for 5 days (ISSO 2I527-2. 2008). Microbial counts were expressed as colony-form- 
ing units per gram of bee pollen (CFU $g^{-1}$ ). For sulfitereducing clostridia counting, aliquots of 10.0. 5.0. I.0 and $0.1 \mathrm{~mL}$ of the initial suspension were added to an empty tube, thermally treated at $80{ }^{\circ} \mathrm{C}$ for $5 \mathrm{~min}$ and covered with ISA (iron sulfite agar) media (Oxoid), and incubated at $37^{\circ} \mathrm{C}$ for 5 days (ISO I52।3, 2003).

\section{Statistical analysis}

The experiments were conducted in a fully randomized manner and all the data obtained were tested regarding normal distribution (Shapiro-Wilk test) and homogeneity of variances (Levene, and Brown-Forsythe tests). The results of the experiments were analyzed statistically in four groups. Each group corresponds to the Brazilian macro-regions (Northeast, Midwest, Southeast, and South) where bee pollen samples were collected from.

The existence of association between the variables: pollen type and proximate analysis (ashes, lipids, proteins and moisture) was analyzed using the Pearson correlation and adopting the coefficient of correlation (r) as the parameter to evaluate the nature (directly or inversely proportional) and the intensity of these correlations (0 to I. with I indicating maximum correlation). In the sets of data in which the normal distributions and, specially, the homogeneity of variances were not observed, non-parametric statistical tests were employed. For the test of correlation, the Spearman correlation test was adopted; for comparing two groups, the Mann-Whitney was employed, and for more than two groups, the Kruskal-Wallis test was employed. The results were expressed as the mean of the results \pm standard deviation. All the statistical analyses were performed using the program STATISTICA 8.0 and adopting the significance level of $5 \%(p<0.05)$.

\section{Results and discussion}

Regarding the physicochemical attributes of the dehydrated bee pollen samples analyzed, in Table I, the samples are observed to be significantly different $(p<0.05)$ for moisture, ash and lipids. Moisture was higher for the samples from the Midwest region than in any other regions $(p<0.05)$ and the average humidity of samples from the northeastern region was higher than in samples from the southern region $(p=0.039)$. The amount of ash was higher in samples from the northeastern region $(p<0.00 \mathrm{I})$. The content of ashes can be influenced by the ability of the plant to accumulate minerals, by the geographical origin, type of soil and floral species (Carpes, Mourão, Alencar, \& Masson, 2009; Martins et al., 20I I).

Martins et al. (20II), evaluating I54 Brazilian bee pollen samples, also found that ash contents were higher for the samples in the Northeast region. The lipid content of the samples from the Northeast and Southeast regions were smaller than the Southern region samples $(p<0.001$ and $p=0.029$, respectively).
The moisture content of the samples presented values between $3.06 \%$ and $8.12 \%$. Out of the 62 samples analyzed, only $17.7 \%$ showed moisture value below $4 \%$ (maximum value provided by the Brazilian Legislation and by the Argentinian regulation). The average value obtained for samples from the southern region of Brazil by Almeida-Muradian et al. (2005), was $7.40 \%$; however, the method used was the gravimetric using vacuum oven at $70{ }^{\circ} \mathrm{C}$. As demonstrated by Melo and AlmeidaMuradian (20II), the method influences the results and the recommended method is the infrared dryer (Almeida-Muradian et al., 20I2). High moisture values were also reported by Bastos, Rocha, Cunha, Carvalho, and Torres (2003) using the method of Karl Fisher for dehydrated bee pollen samples from the States of São Paulo and Minas Gerais, Brazil (average of $8.78 \%$ ). The results aforementioned for researchers showed variability which, according to Marchini, Reis, and Moreti (2006) can be explained by the fact that the dehydrated bee pollen is very hygroscopic and can be affected by environmental conditions.

The results found are similar to those already found, in samples from several Brazilian states, by Arruda, Pereira, Freitas, et al. (20/3), Melo and Almeida-Muradian (20II), Oliveira (2006), Martins et al. (20II), Sattler et al. (20I5). It is important to note that results may vary according to the method of moisture determination employed (e.g., infrared dryer, Karl Fisher, and freeze drying). The variation for moisture results (Table I), points out the difficulty of producers in obtaining a bee pollen that meets the Brazilian legislation requirements (Martins et al., 20I I) and also a legislation that fails to state the method that should be adopted by all producers of beekeeping pollens.

Water content and water activity play an important role in the organoleptic characteristics and the shelf life of the bee pollen. When the values are too high, they can potentially stimulate microbial contamination, especially by fungi and yeasts (Coronel, Grasso, Pereira, \& Fernández, 2004; Morgano et al., 20I I; Nogueira et al., 20I2). It is recommended not to collect bee pollen in rainy days or in very wet days. Moreover, in the processing line, the oven to dehydrate must be adequate; a dehumidifier can also be used in the drying room. As bee pollen is a highly hygroscopic material, glass or hard plastic packaging would be the most appropriate for marketing and storing the product.

Regarding ash content, of the samples analyzed, $96.8 \%$ were in accordance with the maximum value established by the Brazilian Legislation (4\%). Results above $4 \%$ may indicate the presence of contaminants such as dirt, wood and foliage. There is a directly proportional relationship between the values of ashes and the percentages of Cocos nucifera, M. verrucosa, Myrcia and Tapirira. There is an inversely proportional content of ashes with Asteraceae, Euphorbiaceae, Poaceae, according to a preliminary study of botanical origin for the same 62 samples (Freitas, Arruda, Almeida-Muradian, \& Barth, 20I3). 
Table I. Dehydrated bee pollen: chemical, physicochemical analysis, and comparison of the samples by ANOVA method.

\begin{tabular}{|c|c|c|c|c|c|c|c|c|}
\hline Variable & Region & Average & DP & Median & Minimum & Maximum & $N$ & $p$-value* \\
\hline \multirow[t]{5}{*}{ Moisture (\%) } & Northeast & 4.97 & 0.62 & 5.16 & 3.85 & 5.82 & 19 & $<0.001$ \\
\hline & Mid-west & 6.62 & 1.14 & 6.79 & 5.35 & 8.12 & 5 & \\
\hline & Southeast & 4.70 & 0.98 & 4.75 & 3.06 & 6.55 & 25 & \\
\hline & South & 4.18 & 0.44 & 4.34 & $3.4 I$ & 4.67 & 13 & \\
\hline & Total & 4.83 & 0.99 & 4.68 & 3.06 & 8.12 & 62 & \\
\hline \multirow[t]{5}{*}{ Ash (\%) } & Northeast & 3.47 & 0.46 & 3.44 & 2.37 & 4.61 & 19 & $<0.001$ \\
\hline & Mid-west & 2.38 & 0.46 & 2.14 & 1.94 & 2.93 & 5 & \\
\hline & Southeast & 2.89 & 0.40 & 2.96 & 2.31 & 3.78 & 25 & \\
\hline & South & 2.54 & 0.31 & 2.53 & 1.91 & 3.16 & 13 & \\
\hline & Total & 2.95 & 0.55 & 2.97 & 1.91 & 4.61 & 62 & \\
\hline \multirow[t]{5}{*}{ Lipids (\%) } & Northeast & 5.46 & 1.69 & 4.99 & 3.25 & 10.96 & 19 & 0.001 \\
\hline & Mid-west & 6.48 & 1.72 & 5.34 & 5.23 & 8.98 & 5 & \\
\hline & Southeast & 6.26 & 1.33 & 6.12 & 4.16 & 9.09 & 25 & \\
\hline & South & 7.70 & 1.28 & 7.78 & 5.09 & 9.51 & 13 & \\
\hline & Total & 6.33 & 1.64 & 6.08 & 3.25 & 10.96 & 62 & \\
\hline \multirow[t]{5}{*}{ Proteins (\%) } & Northeast & 24.84 & 3.50 & 25.05 & 18.54 & 33.13 & 19 & 0.241 \\
\hline & Mid-west & 23.27 & 7.26 & 23.65 & 16.33 & 34.73 & 5 & \\
\hline & Southeast & 22.96 & 3.67 & 21.63 & 17.84 & 31.67 & 25 & \\
\hline & South & 21.97 & 4.05 & 20.42 & 15.49 & 30.36 & 13 & \\
\hline & Total & 23.35 & 4. 10 & 22.50 & 15.49 & 34.73 & 62 & \\
\hline \multirow[t]{5}{*}{ Fructose (\%) } & Northeast & 16.51 & 4.23 & 15.20 & 10.39 & 25.71 & 19 & 0.600 \\
\hline & Mid-west & 15.16 & 6.11 & 13.62 & 8.08 & 21.52 & 5 & \\
\hline & Southeast & 16.42 & 2.64 & 16.15 & 12.15 & 20.87 & 25 & \\
\hline & South & 15.11 & 2.42 & 14.15 & 11.69 & 19.82 & 13 & \\
\hline & Total & 16.07 & 3.46 & 15.74 & 8.08 & 25.71 & 62 & \\
\hline \multirow[t]{5}{*}{ Glucose (\%) } & Northeast & 13.49 & 4.04 & 12.60 & 2.77 & 20.53 & 19 & 0.177 \\
\hline & Mid-west & 12.66 & 3.29 & 13.77 & 7.95 & 16.67 & 5 & \\
\hline & Southeast & 10.58 & 5.17 & 9.73 & 4.36 & 20.90 & 25 & \\
\hline & South & 10.57 & 5.09 & 7.84 & 4.79 & 17.63 & 13 & \\
\hline & Total & II.64 & 4.80 & 12.07 & 2.77 & 20.90 & 62 & \\
\hline
\end{tabular}

*Descriptive level of statistical test.

The results found are similar to those already found, in samples from several Brazilian states, by Bastos et al. (2003), Almeida-Muradian et al. (2005), Barreto, Funari, Orsi, and Dib (2006), Marchini et al. (2006), Modro, Message, Luz, and Meira Neto (2007), Melo et al. (2009), Arruda, Pereira, Freitas, et al. (2013), Martins et al. (201 I), Carpes et al. (2009), and Sattler et al. (20I5). The level of minerals in bee pollen can vary considerably throughout the year due to differences in the floral source (Taha, 20I5). According to Sattler et al. (20।6), bee pollen samples from southern Brazil have iron, chromium and magnesium as prevalent minerals.

The lipid content obtained in this study ranged between 3.25 and $10.96 \%$ which is in accordance with the limit recommended by the Brazilian Legislation (minimum of 1.8\%). Freitas et al. (2013) used the same 62 samples for determining the botanical origin of each sample. The lipid content had a positive correlation with the bee pollen from Amaranthus, Asteraceae, Poaceae, and Euphorbiaceae. A negative correlation was obtained with lipid content and bee pollen from Anadenanthera, $M$. verrucosa, $C$. nucifera and Myrcia.

Lipid results found are similar to those already found, in samples from several Brazilian states, by Arruda, Pereira, Freitas, et al. (2013), Melo et al. (2009), Funari et al. (2003), Barreto et al. (2005), Marchini et al.
(2006), Bastos et al. (2003), Almeida-Muradian et al. (2005), Carpes et al. (2009), Martins et al. (20l I), and Sattler et al. (2015).

For proteins, the values obtained herein are between 15.49 and $34.73 \%$ which is in accordance with the Brazilian standard that establishes the minimum of $8 \%$. According to a preliminary study of botanical origin (Freitas et al., 2013) involving the same 62 bee pollen samples, proteins showed a positive correlation with $M$. verrucosa and Myrcia, and negative correlation with Amaranthus, Asteraceae, Poaceae and Euphorbiaceae.

Proteins results found are similar to those already found, in samples from several Brazilian states, by Bastos et al. (2003), Funari et al. (2003), Almeida-Muradian et al. (2005), Marchini et al. (2006), Arruda, Pereira, Freitas, et al. (2013), Melo et al. (2009), Modro et al. (2007), Carpes et al. (2009), Martins et al. (20II) and Sattler et al. (2015).

According to the researches by Serra-Bonvehí and Escolà Jordà (1997) and Szczesna (2007), fructose and glucose are the free sugars present in greater concentrations in bee pollen, fructose observably predominating in relation to glucose. The results varied between $8.08 \%$ and $25.71 \%$ and $2.77 \%$ and $20.90 \%$ for fructose and for glucose, respectively (see Table 2 for spike-and-recovery tests for glucose and fructose content). According to a 
Table 2. Dehydrated bee pollen: spike-and-recovery tests for glucose and fructose content.

\begin{tabular}{lccccc}
\hline \multicolumn{4}{c}{ Recovery (\%) } \\
\hline & \multicolumn{3}{c}{ Glucose } & & \multicolumn{2}{c}{ Fructose } \\
\cline { 2 - 3 } \cline { 5 - 6 } Level & Mean & Standard deviation & & Mean & Standard deviation \\
\hline 1 & 98.72 & 7.72 & & 86.60 & 3.93 \\
2 & 89.50 & 4.52 & & 81.90 & 5.55 \\
3 & 86.70 & 6.98 & & 74.60 & 4.98 \\
\hline
\end{tabular}

preliminary study of botanical origin (Freitas et al., 2013) involving the same 62 samples, there is a positive correlation of fructose with C. nucifera and Myrcia, and a negative correlation with $M$. verrucosa. For glucose, there was a positive correlation with Anadenanthera, Eucalyptus, Schinus and Vernonia, and a negative correlation with Asteraceae, Euphorbiaceae, M. caesalpiniaefolia, Poaceae.

The results found are similar to those samples already found, in Brazil (Martins et al., 20II; Sattler et al., 2015), Spain (Serra-Bonvehí \& Escolà Jordà, 1997), Argentina (Coronel et al., 2004), Poland, South Korea and China (Szczesna, 2007), Israel, China, Romania and Spain (Qian, Khan, Watson, \& Fearnl, 2008).

Most of the carbohydrates present in pollen derive from the nectar or from the honey, composing the fluid used by the bees to aggregate pollen balls (Human \& Nicholson, 2006). As a consequence, pollen presents large amounts of reducing sugars, observed in the results herein and in the other works referenced herein. The sum of glucose and fructose was $26.33 \%$, on average. The fructose/glucose rate varied between 0.74 and 5.88. Serra-Bonvehí and Escolà Jordà (1997) found an index oscillating between 1.13 and 1.53 for Spanish dehydrated pollen samples. Szczesna (2007) found values from 1.33 to 1.45 for dehydrated pollen samples from Israel, China and Romania, while Martins et al. (20II), reported rates varying between I.0I and 2.24 in Brazilian dehydrated pollen samples. The fructose/glucose ratio may be related to the glycaemic index (Bogdanov, Jurendic, Sieber, \& Gallmann, 2008; Ischayek \& Kern, 2006; Martins et al., 20II), a measure of the effect food exerts on the blood glucose levels. In honey, the F/G ratio varies between 1.03 and 1.54 (Ischayek \& Kern, 2006); this high ratio is considered the main reason for the low or moderate glycaemic index in some honey varieties. Honey with a smaller F/G ratio tend to have a higher glycaemic index (Foster-Powell, Holt, \& Brand-Miller, 2002; Ischayek \& Kern, 2006). To elucidate the values of the F/G ratio of the Brazilian bee pollen, additional studies are required, especially for the samples that presented values above those reported in other works (Martins et al., 20lI). The samples collected in São Paulo, Santa Catarina and Sergipe presented a F/G ratio exceeding 2.0.

The variability in the centesimal composition found for the bee pollen samples analyzed herein may be explained by the botanical diversity, age, nutritional condition of the plant and environmental conditions of the different production localities, seasons (Barreto et al., 2006; Funari et al., 2003; Herbert \& Shimanuki, 1978) as well as by factors related to the product manipulation and storage (Villanueva, Marquina, Serrano, \& Abellán, 2002).

Molds and yeasts were detected in $60 \%$ of the samples analyzed (Table 3). However, Hervantin (2009) and Coronel et al. (2004) detected the presence of these microorganisms in all the samples analyzed in Brazilian and in Argentinian bee pollen samples, respectively. Hervantin (2009) analyzed dehydrated bee pollen samples from the State of São Paulo and verified that $60 \%$ of the samples presented numbers exceeding $10^{4} \mathrm{CFU} \mathrm{g}^{-1}$. According to Article 785 of the Argentinian Food Code (Argentina, 1990), this number cannot exceed $10^{2} \mathrm{CFU} \mathrm{g}{ }^{-1}$ of pollen.

In Brazil, there is still no law or regulation about microbiological quality control for bee pollen (ANVISA, 200I), making it imperative to establish hygienic-sanitary standards for beekeeping products. Studies about hygienic-sanitary in beekeeping products also provide information to national regulatory agencies to establish microbiological standards. The results obtained by Estevinho et al. (20/2), Nogueira et al. (20/2) and Feás et al. (20/2), were smaller than the ones determined herein in Portuguese organic dehydrated bee pollen samples and commercial bee pollen. From the biological viewpoint, the mold and yeast values are related to the environmental conditions, and are an indication of the adequate or inefficient management of the apiaries (Nogueira et al., 20I2).

Aerobic mesophiles were present in $56 \%$ of the samples, oscillating between $<10$ and $1.26 \times 10^{3}$ (Table 3). The results from the aerobic mesophiles agreed with the standard established by the Argentinian Food Code, which provides a maximum value of $1.5 \times 10^{5} \mathrm{CFU} \mathrm{g}^{-1}$ for aerobic mesophiles in dehydrated bee pollen. The number of aerobic mesophiles reflects the hygienic quality of food or raw material, as well as the processing, handling and storing conditions. The presence of a large number of mesophilic bacteria may indicate excessively contaminated raw material; inadequate cleaning and disinfection of surfaces; insufficient hygiene in food production or preservation; inadequate time/temperature conditions in food production or preservation, or a combination of these circumstances (De-Melo et al., 2016; Estevinho et al., 2012; Feás et al., 2012; Franco \& Landgraf, 2005; Hani et al., 2012; Nogueira et al., 20I2).

Total coliforms, Escherichia coli and Staphylococcus aureus were present in $50,11.3$ and $30.6 \%$ of the samples, respectively (Table 3 ). In the works by Estevinho et al. (20l2), Nogueira et al. (20/2) and Feás et al. (2012) into organic and in commercial pollen produced in Portugal, these microorganisms were absent from all 
Table 3. Results of the microbiological analyses performed for the dehydrated bee pollen samples, grouped by region of collection by Kruskal-Wallis.

\begin{tabular}{|c|c|c|c|c|c|c|c|c|}
\hline Variable & Region & Average & DP & Median & Min & Max & $N$ & $p$-value* \\
\hline Aerobic mesophiles (UFC $\mathrm{g}^{-1}$ ) & $\begin{array}{l}\text { Northeast } \\
\text { Mid-west } \\
\text { Southeast } \\
\text { South } \\
\text { Total }\end{array}$ & $\begin{array}{l}3.51 \times 10^{2} \\
6.80 \times 10^{1} \\
1.57 \times 10^{2} \\
3.51 \times 10^{2} \\
2.50 \times 10^{2}\end{array}$ & $\begin{array}{l}7.15 \times 10^{2} \\
1.30 \times 10^{2} \\
2.40 \times 10^{2} \\
4.41 \times 10^{2} \\
4.73 \times 10^{2}\end{array}$ & $\begin{aligned} 6.33 & \times 10^{1} \\
& <10 \\
& <10 \\
6.33 & \times 10^{1} \\
5.50 & \times 10^{1}\end{aligned}$ & $\begin{array}{l}<10 \\
<10 \\
<10 \\
<10 \\
<10\end{array}$ & $\begin{array}{l}3.00 \times 10^{3} \\
3.00 \times 10^{2} \\
7.13 \times 10^{2} \\
1.27 \times 10^{3} \\
3.00 \times 10^{3}\end{array}$ & $\begin{array}{c}19 \\
5 \\
25 \\
13 \\
62\end{array}$ & 0.212 \\
\hline Yeasts and molds (UFC $\mathrm{g}^{-1}$ ) & $\begin{array}{l}\text { Northeast } \\
\text { Mid-west } \\
\text { Southeast } \\
\text { South } \\
\text { Total }\end{array}$ & $\begin{array}{l}7.62 \times 10^{2} \\
1.90 \times 10^{2} \\
4.11 \times 10^{2} \\
4.97 \times 10^{2} \\
5.19 \times 10^{2}\end{array}$ & $\begin{array}{l}2.10 \times 10^{3} \\
3.78 \times 10^{2} \\
8.44 \times 10^{2} \\
1.13 \times 10^{3} \\
1.37 \times 10^{3}\end{array}$ & $\begin{array}{l}6.71 \times 10^{1} \\
<10 \\
1.17 \times 10^{1} \\
5.00 \times 10^{1} \\
4.80 \times 10^{1}\end{array}$ & $\begin{array}{l}<10 \\
<10 \\
<10 \\
<10 \\
<10\end{array}$ & $\begin{array}{l}8.67 \times 10^{3} \\
8.67 \times 10^{2} \\
3.00 \times 10^{3} \\
4.16 \times 10^{3} \\
8.67 \times 10^{3}\end{array}$ & $\begin{array}{c}19 \\
5 \\
25 \\
13 \\
62\end{array}$ & 0.639 \\
\hline Coliforms (UFC $g^{-1}$ ) & $\begin{array}{l}\text { Northeast } \\
\text { Mid-west } \\
\text { Southeast } \\
\text { South } \\
\text { Total }\end{array}$ & $\begin{array}{l}1.35 \times 10^{2} \\
1.68 \times 10^{1} \\
7.38 \times 10^{1} \\
2.65 \times 10^{1} \\
7.79 \times 10^{1}\end{array}$ & $\begin{array}{l}2.42 \times 10^{2} \\
3.53 \times 10^{2} \\
1.84 \times 10^{2} \\
3.91 \times 10^{1} \\
1.81 \times 10^{2}\end{array}$ & $\begin{array}{c}2.33 \times 10^{1} \\
<1 \\
2.33 \times 10^{1} \\
<1 \\
9.67\end{array}$ & $\begin{array}{l}<1 \\
<1 \\
<1 \\
<1 \\
<1\end{array}$ & $\begin{array}{l}7.67 \times 10^{2} \\
8.00 \times 10^{1} \\
9.00 \times 10^{2} \\
1.27 \times 10^{2} \\
9.00 \times 10^{2}\end{array}$ & $\begin{array}{c}19 \\
5 \\
25 \\
13 \\
62\end{array}$ & 0.482 \\
\hline E. coli $\left(\mathrm{UFC} g^{-1}\right)$ & $\begin{array}{l}\text { Northeast } \\
\text { Mid-west } \\
\text { Southeast } \\
\text { South } \\
\text { Total }\end{array}$ & $\begin{array}{l}4.68 \\
1.00 \\
3.29 \\
5.79 \\
4.06\end{array}$ & $\begin{array}{c}1.24 \times 10^{1} \\
0.00 \\
6.72 \\
1.40 \times 10^{1} \\
1.00 \times 10^{1}\end{array}$ & $\begin{array}{l}<1 \\
<1 \\
<1 \\
<1 \\
<1\end{array}$ & $\begin{array}{l}<1 \\
<1 \\
<1 \\
<1 \\
<1\end{array}$ & $\begin{array}{c}5.30 \times 10^{1} \\
<1 \\
2.80 \times 10^{1} \\
5.10 \times 10^{1} \\
5.30 \times 10^{1}\end{array}$ & $\begin{array}{c}19 \\
5 \\
25 \\
13 \\
62\end{array}$ & 0.839 \\
\hline S. aureus (UFC $\mathrm{g}^{-1}$ ) & $\begin{array}{l}\text { Northeast } \\
\text { Mid-west } \\
\text { Southeast } \\
\text { South } \\
\text { Total }\end{array}$ & $\begin{array}{c}2.35 \times 10^{1} \\
<1.00 \\
1.19 \times 10^{1} \\
1.78 \times 10^{2} \\
4.94 \times 10^{1}\end{array}$ & $\begin{array}{c}5.03 \times 10^{1} \\
0.00 \\
2.52 \times 10^{1} \\
5.56 \times 10^{2} \\
2.53 \times 10^{2}\end{array}$ & $\begin{array}{c}<1 \\
<1 \\
<1 \\
2.25 \times 10^{1} \\
<1\end{array}$ & $\begin{array}{l}<1 \\
<1 \\
<1 \\
<1 \\
<1\end{array}$ & $\begin{array}{c}2.00 \times 10^{2} \\
<1 \\
9.00 \times 10^{1} \\
2.03 \times 10^{3} \\
2.03 \times 10^{3}\end{array}$ & $\begin{array}{c}19 \\
5 \\
25 \\
13 \\
62\end{array}$ & 0.048 \\
\hline
\end{tabular}

*Descriptive level of statistical test.

the samples. Hani et al. (20/2) reported total coliforms in bee pollen $<10$ to $10^{4} \mathrm{CFU} \mathrm{g}^{-1}$. De-Melo et al. (2016) reported the presence of total coliforms in bee pollen $<10$ to $2.80 \times 10^{3} \mathrm{CFU} \mathrm{g}^{-1}$. Coliform contamination is an indicator of the hygienic conditions of the manufacturing process, once they are easily inactivated by sanitizers and have a large capacity of forming colonies at different points of the processing plant, when sanitization is faulty (see Table 3).

Sulfite-reducing Clostridium spores were absent from all the 62 samples analyzed (Clostridium data are not presented in Table 3). The same was observed by Estevinho et al. (20|2), Nogueira et al. (20|2), Feás et al. (20|2), Coronel et al. (2004) and De-Melo et al. (2016).

According to a preliminary study of botanical origin (Freitas et al., 2013) involving the same 62 samples, an inversely proportional relationship between the percentages of Cecropia was verified from the aerobic mesophiles, molds, yeasts and total coliform numbers. The total coliforms also presented a positive correlation with $M$. caesalpiniaefolia and $M$. scabrella. A positive correlation of $E$. coli with Amaranthus was found. For $S$. aureus, a positive correlation was verified with Ambrosia and Asteraceae.

All the 62 samples from eight Brazilian States and from the Federal District presented contamination by microorganisms. Only sulfite-reducing clostridia spores were absent from all the 62 samples analyzed. A stricter control on those handling the samples during the production is suggested, which must also occur at the depots along the product fractioning and packaging. The parameters assessed herein are not provided in the specific legislation for bee pollen and should have their inclusion considered by regulatory agencies. This would possibly establish specific microbiological standards for bee pollen. The samples analyzed generally correspond to the limits established by the incipient Brazilian Legislation for the ash, lipid and protein parameters, except for the moisture content of the samples, which exceeded the $4 \%$ limit established by the Brazilian Legislation for dehydrated samples. Result variation for moisture can also be attributed to data obtained by different methods. A regulatory legislation should state the method to be adopted by all producers of beekeeping pollens.

\section{Disclosure statement}

No potential conflict of interest was reported by the authors.

\section{Funding}

This work was supported by the São Paulo Research Foundation (FAPESP) [grant number 2009/52/63-5]; Coordination for the Improvement of Higher Education Personnel (CAPES).

\section{ORCID}

Vanilda Aparecida Soares de Arruda (D) http://orcid.org/00000002-7498-87I5 
Elias da Silva Araújo (D) http://orcid.org/0000-0002-2507-793 I André Luís de Castro Peixoto (D) http://orcid.org/0000-0003-26552025

Ligia Bicudo de Almeida-Muradian (D) http://orcid.org/0000-000I5322-1358

\section{References}

ANVISA. (200I). Resolução RDC n.12, de 02 de janeiro de 2001 . Aprova o regulamento técnico sobre padrões microbiológicos para alimentos. Retrieved from http://bvsms.saude.gov.

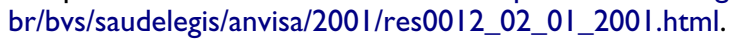

Almeida-Muradian, L.B., Arruda, V.A.S., \& Barreto, L.M.R.C. (20I2). Manual of Beekeeping pollen quality control. São Paulo: APACAME.

Almeida-Muradian, L.B., Pamplona, L.C., Coimbra, S., \& Barth, O.M. (2005). Chemical composition and botanical evaluation of dried bee pollen pellets. Journal of Food Composition and Analysis, 18, 105-III.

Almeida-Muradian, L.B., \& Penteado, M.D.V.C. (2007). Health Surveillance: topics on legislation and food analysis. Rio de Janeiro: Guanabara Koogan.

Argentina. (1990). Administración Nacional de Medicamentos, Alimentos y Tecnologia Médica. Alimentos. Código Alimentario Argentino. (Capítulo X: Alimentos Azucarados: Artículo 785 - Resolucion 1550 de 12 de dezembro de 1990). Retrieved from: http:// www.anmat.gov.ar/alimentos/codigoa/Capitulo_X.pdf

Arruda, V.A.S., Freitas, A.S., Barth, O.M., Estevinho, M.L.M., \& Almeida-Muradian, L.B. (20|3). Biological properties of coconut bee pollen collected in the Northeast Region of Brazil. Magistra, 25, II 2-I74.

Arruda, V.A.S., Pereira, A.A.S., Estevinho, M.L.M., \& AlmeidaMuradian, L.B. (20I3). Presence and stability of B complex vitamins in bee pollen using different storage conditions. Food and Chemical Toxicology, 5I, I43-148.

Arruda, V.A.S., Pereira, A.A.S., Freitas, A.S., Barth, O.M., \& Almeida-Muradian, L.B. (2013). Dried bee pollen: B complex vitamins, physicochemical and botanical composition. Journal of Food Composition and Analysis, 29, 100-105.

Barreto, L.M.R.C., Funari, S.R.C., \& Orsi, R.O. (2005). Composition and quality of bee pollen from seven Brazilian State and Federal District. Boletim de Indústria Animal, 62, 167-175.

Barreto, L.M.R.C., Funari, S.R.C., Orsi, R.O., \& Dib, A.P.S. (2006). Pollen production in Brazil. Taubaté: Cabral.

Bastos, D.H.M., Rocha, C.I., Cunha, I.B.S., Carvalho, P.O., \& Torres, E.A.S. (2003). Composition and quality of bee-collected pollen commercialized in some country towns in São Paulo and Minas Gerais - Brazil. Revista do Instituto Adolfo Lutz, 62, 239-244.

Bogdanov, S., Jurendic, T., Sieber, R., \& Gallmann, P. (2008). Honey for nutrition and health: A review. Journal of the American College of Nutrition, 27, 677-689.

Burgner, E., \& Feinberg, M. (1992). Determination of mono and disaccharides in foods by interlaboratory study: Quantitation of bias components for liquid chromatography. Journal of AOAC International, 75, 443-464.

Campos, M.G., Bogdanov, S., Almeida-Muradian, L.B., Szczesna, T., Mancebo, Y., Frigerio, C., \& Ferreira, F. (2008). Pollen composition and standardisation of analytical methods. Journal of Apicultural Research, 47, |54-16|. doi:10.1080/ 00218839.2008 .11101443

Carpes, S.T., Mourão, G.B., Alencar, S.M., \& Masson, M.L. (2009). Chemical composition and free radical scavenging activity of Apis mellifera bee pollen from Southern Brazil. Brazilian Journal of Food Technology, 12, 220-229.
Coronel, B.B., Grasso, D.S.C., Pereira, G., \& Fernández, A. (2004). Caracterización bromatológica del pólen apícola Argentino. Ciencia Docencia y Tecnología, 29, 145-181. Retrieved from http://www.redalyc.org/articulo.oa?id=| 4502906

De-Melo, A.A.M., Estevinho, M.L., \& Almeida-Muradian, L.B. (20I5). A diagnosis of the microbiological quality of dehydrated bee-pollen produced in Brazil. Letters in Applied Microbiology, 6I, 477-483.

De-Melo, A.A.M., Estevinho, M.L.M.F., Sattler, J.A.G., Souza, B.R., Freitas, A.S., Barth, O.M., \& Almeida-Muradian, L.B. (20I6). Effect of processing conditions on characteristics of dehydrated bee-pollen and correlation between quality parameters. LWT-Food Science and Technology, 65, 808-8I5.

Estevinho, L.M., Rodrigues, S., Pereira, A.P., \& Feás, X. (20/2). Portuguese bee pollen: palynological study, nutritional and microbiological evaluation. International Journal of Food Science \& Technology, 47, 429-435.

Fatrcová-Šramková, K., Nôžková, J., Kačániová, M., Máriássyová, M., Rovná, K., \& Stričík, M. (20I3). Antioxidant and antimicrobial properties of monofloral bee pollen. Journal of Environmental Science and Health, Part B, 48, I33-138.

Feás, X., Vázquez-Tato, M.P., Estevinho, L., Seijas, J.A., \& Iglesias, A. (20I2). Organic bee pollen: Botanical origin, nutritional value, bioactive compounds, antioxidant activity and microbiological quality. Molecules, 17, 8359-8377.

Foster-Powell, K., Holt, S.H., \& Brand-Miller, J.C. (2002). International table of glycemic índex and glycemic load values: 2002. American Journal of Clinical Nutrition, 76, 5-56.

Franco, B.D.G.M., \& Landgraf, M. (2005). Microbiologia dos alimentos. São Paulo: Atheneu.

Freitas, A.S., Arruda, V.A.S., Almeida-Muradian, L.B., \& Barth, O.M. (2013). The botanical profiles of dried bee pollen loads collected by Apis mellifera (Linnaeus) in Brazil. Sociobiology, 60, 56-64. http://www.arca.fiocruz.br/handle/icict/ 12677

Funari, S.R.C., Rocha, H.C., Sforcin, J.M., Filho, H.G., Curi, P.R., Gomes Dierckx, S.M.A., ... Oliveira Orsi, R. (2003). Composições bromatológica e mineral de pólen coletado por abelhas africanizadas (Apis mellifera L.) em Botucatu, Estado de São Paulo. Archivos Latinoamericanos de Producción Animal, II, 88-93.

Gabriele, M., Parri, E., Felicioli, A., Sagona, S., Pozzo, L., Biondi, C., ... Pucci, L. (20I5). Phytochemical composition and antioxidant activity of Tuscan bee pollen of different botanic origins. Italian Journal of Food Science, 27, 248-259.

Gomes, S., Dias, L., Moreira, L., Rodrigues, P., \& Estevinho, L.M. (20/0). Physicochemical, microbiological and antimicrobial properties of commercial honeys from Portugal. Food and Chemical Toxicology, 48, 544-548.

Hani, B., Dalila, B., Saliha, D., Harzallah, D., Ghadbane, M., \& Khennouf, S. (20/2). Microbiological sanitary aspects of pollen. Advances in Environmental Biology, 6, 14I5-1420.

Herbert, Jr., E.W., \& Shimanuki, H. (1978). Chemical composition and nutritive value of bee-collected and bee-stored pollen. Apidologie, 9, 33-40.

Hervantin, H.L. (2009) Avaliação microbiológica e fisico-química do pólen apicola in natura e desidratado sob diferentes temperaturas (Master's thesis). Faculdade de Engenharia de Alimentos, Universidade Estadual de Campinas, Campinas.

Human, H., \& Nicholson, S.W. (2006). Nutritional content of fresh, bee-collected and stored pollen of Alloe greatheadii var. davyana (Asphodelaceae). Phytochemistry, 67, $486-1492$.

Ischayek, J.I., \& Kern, M. (2006). US honeys varying in glucose and fructose content elicit similar glycemic indexes. Journal of the American Dietetic Association, 106, 1260-1262. 
Marchini, L.C., Reis, V.D.A., \& Moreti, A.C.C.C. (2006) Composição físico-química de amostras de pólen coletado por abelhas Africanizadas Apis mellifera (Hymenoptera: Apidae) em Piracicaba, Estado de São Paulo. Ciência Rural, 36, 949-953. doi:I0.I590/S0I03-8478200600030 0034.

Martins, M.C.T., Morgano, M.A., Vicente, E., Baggio, S., \& Rodriguez-Amaya, D.B. (20II). Physicochemical composition of bee pollen from eleven Brazilian states. Journal of Apicultural Science, 55, 107-I I6.

Melo, I.L.P., \& Almeida-Muradian, L.B. (20II). Comparison of methodologies for moisture determination on dried bee pollen samples. Ciência e Tecnologia de Alimentos, 31, 194-197.

Melo, I.L.P., Freitas, A.S., Barth, O.M., \& Almeida-Muradian, L.B. (2009). Correlation between nutritional composition and floral origin of dried bee pollen. Revista do Instituto Adolfo Lutz, 58, 346-353.

Modro, A.F.H., Message, D., Luz, C.F.P., \& Meira Neto, J.A.A. (2007). Nutritional composition and quality of bee pollen collected in Minas Gerais, Brazil. Pesquisa Agropecuária Brasileira, 42, 1057-1065.

Morgano, M.A., Milani, R.F., Martins, M.C.T., \& RodriguezAmaya, D.B. (20II). Determination of water content in Brazilian honey bee collected pollen by Karl Fischer titration. Food Control, 22, 1604-1608.

Mundargi, R.C., Potroz, M.G., Park, S., Shirahama, H., Lee, J.H., Seo, J., \& Cho, N.J. (2016). Natural sunflower pollen as a drug delivery vehicle. Small, 12, II67.

Nardoni, S., D'Ascenzi, C., Rocchigiani, G., Moretti, V., \& Mancianti, F. (20I6). Occurrence of molds from bee pollen in Central Italy - A preliminary study. Annals of Agricultural and Environmental Medicine, 23, 103-105. doi:10.5604/ I2321966.II96862

Nogueira, C., Iglesias, A., Feás, X., \& Estevinho, L.M. (2012) Commercial bee pollen with different geographical origins: A comprehensive approach. International Journal of Molecular Sciences, 13, III I73-I I I87.

Oliveira, K.C.L.S. (2006). Characterization of bee pollen and use of antioxidant vitamins as indicators of the dehydration process (master thesis). São Paulo: Faculdade de Ciências Farmacêuticas - Universidade de São Paulo.
Puig-Peña, Y., Del-Risco-Ríos, C.A., Álvarez-Rivera, V.P., LeivaCastillo, V., \& García- Neninger, R. (20/2). Comparación de la calidad microbiológica del polen apícola fresco y después de un proceso de secado. Revista CENIC. Ciencias biológicas, 43, 23-27.

Qian, W.L., Khan, Z., Watson, D.G., \& Fearnl, E.J. (2008). Analysis of sugars in bee pollen and propolis by ligand exchange chromatography in combination with pulsed amperometric detection and mass spectrometry. Analysis, 2I, 78-83.

Sattler, J.A.G., de Melo, I.L.P., Granato, D., Araújo, E., Freitas, A.S., Barth, O.M., ... Almeida-Muradian, L.B. (20I5). Impact of origin on bioactive compounds and nutritional composition of bee pollen from southern Brazil: A screening study. Food Research International, 77, 82-91.

Sattler, J.A.G., De-Melo, A.A.M., Nascimento, K.S.D., ManciniFilho, J., Sattler, A., \& Almeida-Muradian, L.B. (2016) Essential minerals and inorganic contaminants (barium, cadmium, lithium, lead and vanadium) in dried bee pollen produced in Rio Grande do Sul State, Brazil. Food Science and Technology. doi:10.1590/1678-457X.0029.

Serra-Bonvehí, J., \& Escolà Jordà, R. (1997). Nutrient composition and microbiological quality of honey bee-collected pollen in Spain. Journal of Agricultural and Food Chemistry, $45,725-732$.

Szczesna, T. (2007). Study on the sugar composition of honey bee-collected pollen. Journal of Apicultural Science, 5I, I5-22.

Taha, E.K.A. (20I5). Chemical composition and amounts of mineral elements in honey bee- collected pollen in relation to botanical origin. Journal of Apicultural Science, 59, 75-81.

Torres, A., Guinand, J., \& Guerra, M. (2003). Propiedades nutricionales y estabilidad de los componentes de los alimentos. Efecto del procesamiento sobre el valor nutricional de los alimentos, $1,1-18$.

Villanueva, M.T.O., Marquina, A.D., Serrano, R.B., \& Abellán, G.B. (2002). The importance of bee-collected pollen in the diet: A study of its composition. International Journal of Food Sciences and Nutrition, 53, 217-224.

Yang, K., Wu, D., Ye, X., Liu, D., Chen, J., \& Sun, P. (2013). Characterization of chemical composition of bee pollen in China. Journal of Agricultural and Food Chemistry, 6I, 708-718. 